\title{
TU/e EnNHOUN

\section{The promoting role of polycations in the cobalt(II) phthalocyanine tetrasodium sulfonate catalysed oxidation of thiols}

Citation for published version (APA):

Brouwer, W. M., Piet, P., \& German, A. L. (1985). The promoting role of polycations in the cobalt(II) phthalocyanine tetrasodium sulfonate catalysed oxidation of thiols. Journal of Molecular Catalysis, 31(2), 169182. https://doi.org/10.1016/0304-5102(85)85058-6

DOI:

10.1016/0304-5102(85)85058-6

Document status and date:

Published: 01/01/1985

Document Version:

Publisher's PDF, also known as Version of Record (includes final page, issue and volume numbers)

\section{Please check the document version of this publication:}

- A submitted manuscript is the version of the article upon submission and before peer-review. There can be important differences between the submitted version and the official published version of record. People interested in the research are advised to contact the author for the final version of the publication, or visit the DOI to the publisher's website.

- The final author version and the galley proof are versions of the publication after peer review.

- The final published version features the final layout of the paper including the volume, issue and page numbers.

Link to publication

\footnotetext{
General rights

- You may freely distribute the URL identifying the publication in the public portal. follow below link for the End User Agreement:

www.tue.nl/taverne

\section{Take down policy}

If you believe that this document breaches copyright please contact us at:

openaccess@tue.nl

providing details and we will investigate your claim.
}

Copyright and moral rights for the publications made accessible in the public portal are retained by the authors and/or other copyright owners and it is a condition of accessing publications that users recognise and abide by the legal requirements associated with these rights.

- Users may download and print one copy of any publication from the public portal for the purpose of private study or research.

- You may not further distribute the material or use it for any profit-making activity or commercial gain

If the publication is distributed under the terms of Article $25 \mathrm{fa}$ of the Dutch Copyright Act, indicated by the "Taverne" license above, please 


\title{
THE PROMOTING ROLE OF POLYCATIONS IN THE COBALT(II) PHTHALOCYANINE TETRASODIUM SULFONATE CATALYSED OXIDATION OF THIOLS
}

\author{
W. M. BROUWER, P. PIET and A. L. GERMAN
}

Laboratory of Polymer Chemistry, Eindhoven University of Technology, 5600 MB Eindhoven (The Netherlands)

(Received April 24, 1984 ; accepted September 20, 1984)

\section{Summary}

The oxidation of 2-mercaptoethanol with polymer-bound cobalt(II) phthalocyanine catalysts has been investigated. Poly(vinyl amine) (PVAm), poly(ethylenimine) (PEI), poly(L-lysine) (PLL) and 2,4-, 2,6- and 2,10ionene hydroxide have been studied as polymeric ligands. All these ligands appear to enhance the reaction rate considerably in comparison with their monomeric analogues and all exhibit a similar behaviour towards the effect of salt and $\mathrm{pH}$. The reaction rate appears to increase virtually linearly with the linear charge density on the ionenes, which is consistent with recent findings for copolymers of vinyl amine and vinyl alcohol.

Three main parameters seem to provide the enhanced polycationic catalytic effect: a high linear charge density on the polymer, a large amount of base groups in the polymer domain and a low ionic strength for the reaction solution. Furthermore, a comparison of the linear charge density, catalytic activity and activation parameters for the ionene catalysts with those obtained earlier for the vinyl amine-vinyl alcohol copolymers shows that the presence of hydrophilic side-groups has a promoting effect on the oxidation of the hydrophilic thiol. From catalyst re-use experiments, it appears that the polyamine catalysts (PVAm, PEI and PLL) have a poor stability, but that the ionene hydroxides can be re-used many times, probably as a result of the chemical inertness of the quaternary ammonium groups in the ionenes.

\section{Introduction}

Cobalt(II) phthalocyanine is a well-known catalyst for the oxidation of thiols to disulfides [1]:

$4 \mathrm{RSH}+\mathrm{O}_{2} \longrightarrow 2 \mathrm{RSSR}+2 \mathrm{H}_{2} \mathrm{O}$

Attachment of water-soluble cobalt(II) phthalocyanine tetrasodium sulfonate $\left(\mathrm{CoPc}\left(\mathrm{NaSO}_{3}\right)_{4} ; \mathrm{Fig} .1\right.$ ) to poly(vinyl amine) (PVAm) caused a large 


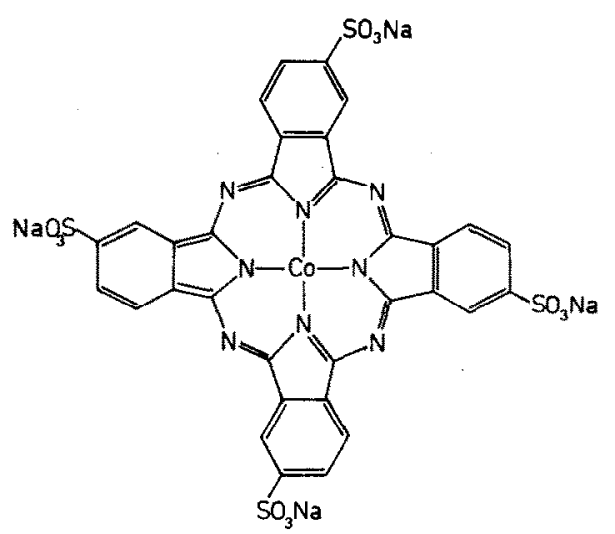

Fig. 1. Chemical structure of cobalt(II) phthalocyanine tetrasodium sulfonate.

enhancement in the rate in comparison to the monomeric analogue 1,3propanediamine [2]. For this particular polymeric catalyst system the effect of $\mathrm{pH}[3]$, ionic strength, substrate concentration, oxygen pressure, temperature [4] and molecular weight of the polymeric ligand [2] on the oxidation rate of 2-mercaptoethanol (RSH) to 2,2-dithiodiethanol (RSSR) was investigated. The polymeric catalyst exhibited enzyme-like behaviour, e.g. Michaelis-Menten kinetics (Scheme 1), with respect to both thiol and oxygen, and a bell-shaped $\mathrm{pH}$ dependence.

$\mathrm{E}+\mathrm{S}+\mathrm{O}_{2} \rightleftarrows \mathrm{O}_{2}-\mathrm{E}-\mathrm{S} \longrightarrow \mathrm{E}+\mathrm{P}$

(E stands for polymer-bound $\mathrm{CoPc}\left(\mathrm{NaSO}_{3}\right)_{4} ; \mathrm{S}$ for substrate (thiol) and $\mathrm{P}$ for products)

Scheme 1.

The enhanced polymeric catalyst activity was partially attributed to the prevention of the dimerisation of $\mathrm{CoPc}\left(\mathrm{NaSO}_{3}\right)_{4}$ by the basic polymer coils, and to the enrichment of these coils with thiol anions, the reactive species. The attachment of $\mathrm{CoPc}\left(\mathrm{SO}_{3}\right)_{4}{ }^{4-}$ to the polymer was attributed to coordinative and Coulombic interaction $[5,6]$, but the nature of the interaction in terms of chemical structure has not as yet been elucidated.

From catalytic experiments using copolymers of vinyl amine and vinyl alcohol as polymeric ligands, it could be deduced that the reaction rate is linearly dependent on the positive charge density on these ligands [7].

In order to check the general validity of the concepts used to account for the catalytic behaviour of the $\mathrm{CoPc}\left(\mathrm{NaSO}_{3}\right)_{4} / \mathrm{PVAm}$ catalyst (i.e. the suggestion that the polymer charge density and the basic groups are the most important parameters which determine the polymeric cataly tic activity), the present investigation has been focused at other types of basic polymer. Thus, branched poly(ethylenimine) (PEI), poly(L-lysine) (PLL) and poly(ammonium hydroxides), also known as ionenes [8], have been introduced as ligands for $\mathrm{CoPc}\left(\mathrm{NaSO}_{3}\right)_{4}$. These ligands were chosen since the polymers 
differ considerably in chemical structure and in the location of the ionic charges with respect to the main polymer chain. When charged, these polymers have an extended conformation in salt-free aqueous solutions, due to repulsion between like charged chain segments. The results obtained are compared and discussed with those obtained from the $\mathrm{CoPc}\left(\mathrm{NaSO}_{3}\right)_{4} / \mathrm{PVAm}$ catalyst system. Finally, the performance of the various polymeric catalysts in re-use experiments has also been tested.

\section{Experimental}

Poly(vinyl amine hydrochloride) (Polysciences Inc.), poly(ethylenimine) (Fluka) and poly(L-lysine) (Polysciences Inc.) were used without further fractionation or purification. 2,4-, 2,6- and 2,10-ionenes were prepared as equivolume mixtures of dimethyl formamide and methanol, containing stoichiometric amounts of tetramethylethane diamine and dibromo-butane, -hexane and -decane $\left(3 \mathrm{~mol} \mathrm{dm}^{-3}\right)$, respectively. The solutions were left undisturbed at room temperature for 2 weeks. The polymers were precipitated in acetone, filtered and purified by repeated dissolution in water and precipitation in acetone. The final products were dried at $50{ }^{\circ} \mathrm{C}$ under vacuum. Carbon, nitrogen and hydrogen analysis indicated that the samples had the desired composition. As estimations of the molecular weights of the ionenes by vapour pressure or membrane osmometry were unsuccessful [9], the intrinsic viscosities $[\eta]$ at $25{ }^{\circ} \mathrm{C}$ in $0.4 \mathrm{M} \mathrm{KBr}$ were used as rough estimates of the molecular weights. For 2,4-, 2,6- and 2,10-ionene bromides, $[\eta]$ was $0.08,0.08$ and $0.06 \mathrm{dl} \mathrm{g}^{-1}$, respectively. The corresponding molecular weights estimated using the Mark-Houwink constants for 3,4ionene bromide [10] gave $\bar{M}_{\mathrm{w} 2,4-}=\bar{M}_{\mathrm{w} 2,6-}=10^{4} \mathrm{~g} \mathrm{~mol}^{-1}$ and $\bar{M}_{\mathrm{w} 2,10^{-}}=6 \times$ $10^{3} \mathrm{~g} \mathrm{~mol}^{-1}$, respectively.

All the polymers were eluted through an Amberlite 401 IRA anionexchange column, in order to obtain the amine form of the polyamines or the hydroxide form of the ionene bromides. After elution, the polymers were stored under nitrogen. The polymer concentrations, expressed as the monomolar concentration of ionisable or ionised groups, were determined by potentiometric titration in $2 \mathrm{M} \mathrm{NaCl}$, with the exception of PEI where the method failed [11]. In this case the concentration as provided by the supplier was employed.

Potentiometric titrations were carried out under nitrogen with $\mathrm{HCl}$ (Titrisol ampoules, Merck), a Radiometer Copenhagen titration apparatus fitted with a GK $2401 \mathrm{~B}$ pH electrode being used. Titration times were always greater than $20 \mathrm{~min}$ in order to obtain reproducible results. The degree of ionisation (i.e. protonation) of the polyamines was calculated from the following equation:

$\sigma=\frac{c_{\mathrm{H}^{+}} \text {(added) }}{-c_{\mathrm{H}^{+}} \text {(Iree) }}+c_{\mathrm{OH}^{-}{ }_{\text {(Iree) }}}$ 
where $c_{\mathrm{H}^{+}}$(added) is the proton concentration resulting from the addition of $\mathrm{HCl}, c_{\mathrm{H}^{+}}{ }_{\text {(free) }}$ and $c_{\mathrm{OH}^{-}}{ }_{\text {(free) }}$ are the concentrations of free protons and hydroxyl ions measured by titration, and $c_{-\mathrm{N}}$ is the concentration of titratable groups. The $\mathrm{H}_{2} \mathrm{O}_{2}$ content was determined iodometrically as described previously [4].

The polymeric catalysts were prepared by mixing aqueous solutions of $\mathrm{CoPc}\left(\mathrm{NaSO}_{3}\right)_{4}$ and polymer, resulting in a polymer-attached organometallic complex. Catalytic measurements were carried out in a Warburg apparatus, equipped with a mechanical stirrer and a digital oxygen flow meter. A stirring speed of $2300 \mathrm{rpm}$ was maintained, although this was not critical since somewhat lower or higher stirring speeds did not affect the oxygen uptake. Initial rates were calculated from the oxygen consumption during the first minute of reaction. The $\mathrm{pH}$ was adjusted by adding $\mathrm{HCl}(0.01 \mathrm{M})$ or $\mathrm{NaOH}(0.3 \mathrm{M})$. A more detailed description has been published previously [4].

\section{Results and discussion}

The ionised state of the polymers

A summary is provided in Table 1 of the chemical structures of the basic polymers employed in the investigations. During the catalytic experiments with the polymeric catalysts, $\mathrm{pH}$ values between 7 and 8 were attained as a result of the large excess of the weakly acidic thiol to basic polymer groups $\left(c_{\mathrm{RSH}} / c_{-\mathrm{N}} \approx 200\right)$. In this $\mathrm{pH}$ region all the polymers employed were positively charged, as appears from the titration plots shown in Fig. 2. The degree of ionisation is dependent on the $\mathrm{pH}$ for the polyamines (PEI, PVAm and PLL), in contrast to the ionene hydroxide polymers which carry permanent charges. Titration of the latter reveals strong base-strong acid titration behaviour, as expected.

Catalytic effects of the polymers

In order to investigate the catalytic effects of these polymers on the oxidation of 2-mercaptoethanol, the oxidation rates of polymerattached $\mathrm{CoPc}\left(\mathrm{NaSO}_{3}\right)_{4}$ have been compared with the oxidation rates of $\mathrm{CoPc}\left(\mathrm{NaSO}_{3}\right)_{4}$ in the presence of the monomeric analogues (see Table 2). From the results of these experiments, the following important conclusions may be drawn:

1. It is obvious that the polymers cause an increase in the observed rate. Moreover, the observation that all polycations investigated lead to large increases in catalytic activity, provided that basic functionalities are also present, is indicative of true polyelectrolyte catalysis in which long-range interactions between the substrate and the polymer predominate. The precise structure of the polymer, viz. the location of the charge (whether it is inside or outside the main chain) or the kind of basic group present (amine or $\mathrm{OH}^{-}$), seems to be of minor importance.

2. Although axial coordination effects associated with the metal centre in $\mathrm{CoPc}\left(\mathrm{NaSO}_{3}\right)_{4}$ may arise in polyamines [5], these effects do not seem to 


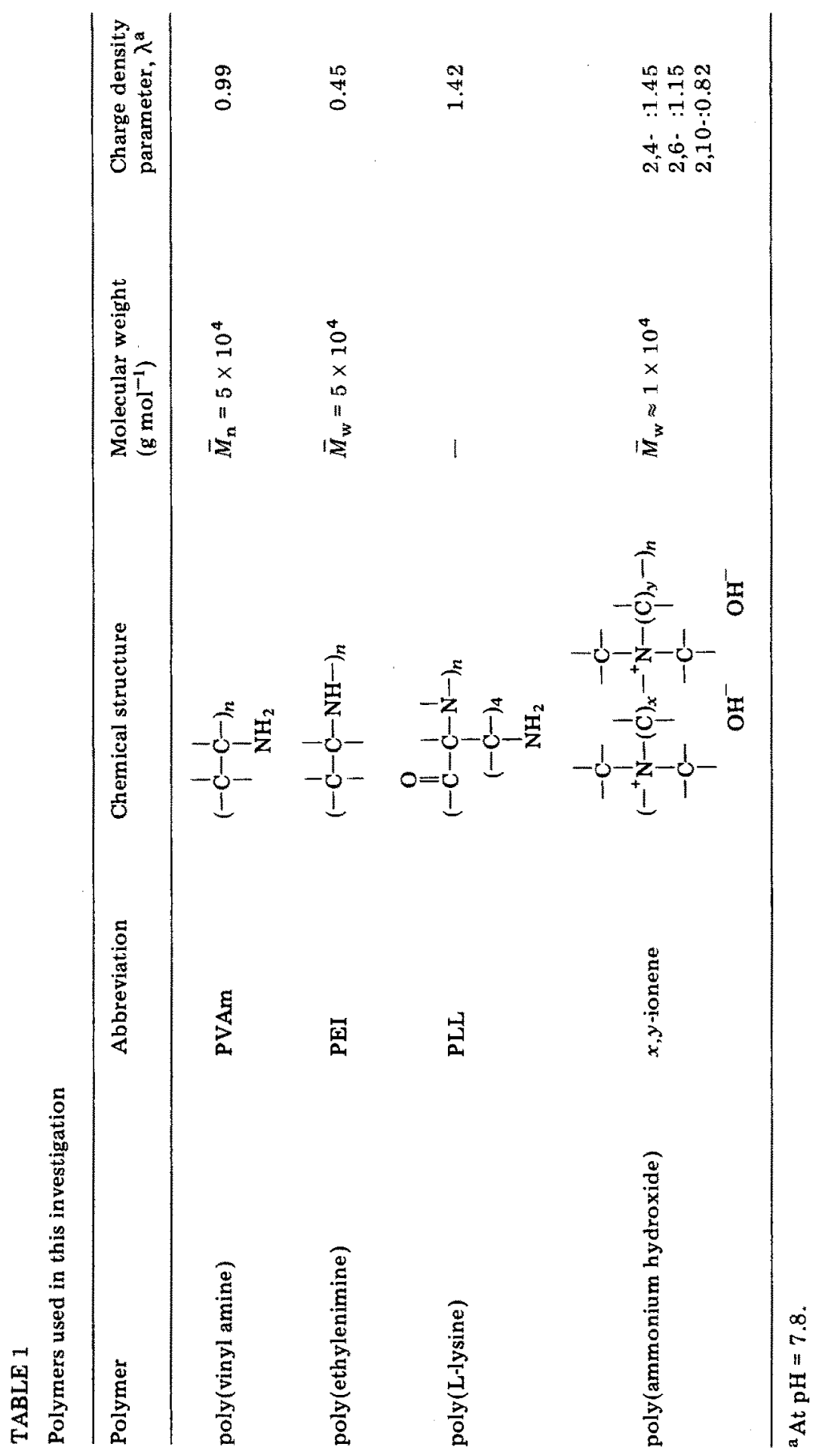



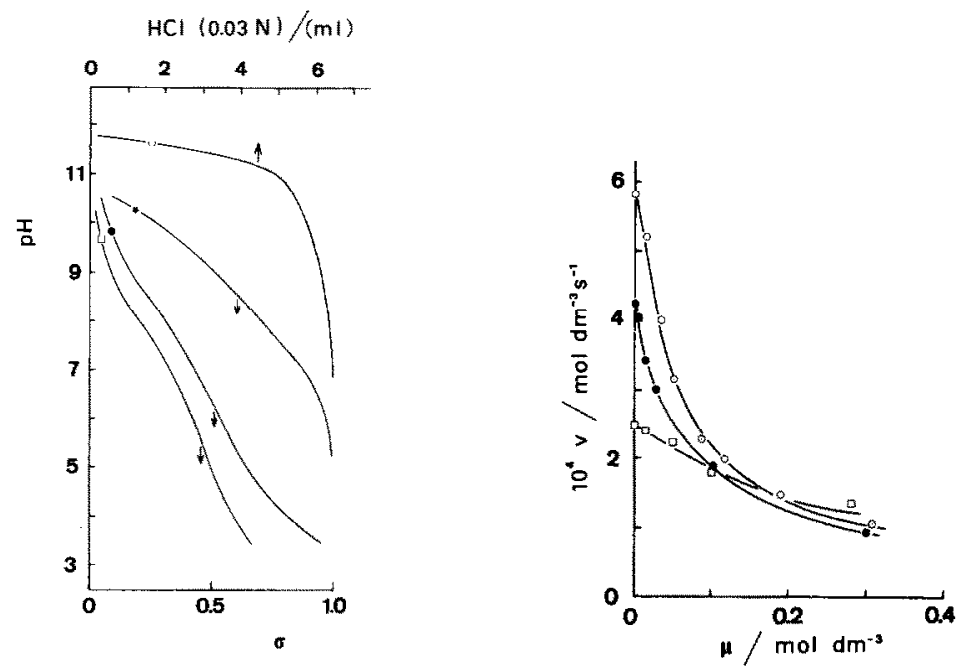

Fig. 2. Titration plots for basic polymers employed. For the various polyamines studied, the $\mathrm{pH}$ is plotted versus the degree of protonation, $\sigma$ (lower scale), whilst for 2,4-ionene hydroxide a plot of $\mathrm{pH}$ versus the amount of $\mathrm{HCl}$ added is depicted (upper scale). The various curves are identified as follows: $0,2,4$-ionene hydroxide $\left(c_{-\mathrm{N}}=6 \times 10^{-3} \mathrm{M}\right)$; $\star$, poly(L-lysine) $\left(c_{-\mathrm{N}}=10^{-3} \mathrm{M}\right) ; \bullet$, poly(vinyl amine) $\left(c_{-\mathrm{N}}=10^{-2} \mathrm{M}\right)$; and $\square$, poly* (ethylenimine) $\left(c_{-\mathrm{N}}=1.6 \times 10^{-2} \mathrm{M}\right)$.

Fig. 3. Effect of ionic strength $(\mathrm{NaCl})$ on the activity of the polymeric catalyst. Reaction conditions: $c_{\mathrm{CoPc}\left(\mathrm{NaSO}_{3}\right)_{4}}=1.9 \times 10^{-7} \mathrm{M} ; c_{-\mathrm{N}}=10^{-3} \mathrm{M}$; and $c_{\mathrm{RSH}}=0.19 \mathrm{M}$. The various curves are identified as follows: $0,2,4$-ionene hydroxide $(\mathrm{pH}=7.5)$; , poly(vinyl amine) $(\mathrm{pH}=7.2)$; and $\square$, poly (ethylenimine) $(\mathrm{pH}=7.0)$.

play an important role in the catalysis mechanism since the 2,4-ionene appears to increase the rate considerably despite lacking any coordinative ability. Moreover, the monomeric amines which possess coordinative abilities lead to relatively low activities.

3 . The absence of lone-pair electrons in the ionenes means that hydrogen bonding can be ruled out of any substrate-polymer binding.

4. All the polymeric catalysts investigated in this study exhibited high apparent activities. Turnover numbers were in the range $1-4 \times 10^{3} \mathrm{~s}^{-1}$.

\section{Effect of salt addition}

The influence of salt $(\mathrm{NaCl})$ on the catalytic activity was investigated for the 2,4-ionene, PVAm and PEI (Fig. 3). The resulting increase in the ionic strength leads to a decrease in the reaction rate for all the cations investigated. This result may indicate the importance of electrostatic effects during polymeric catalysis, and the enhanced salt effect with polycations of higher charge density supports this suggestion. However, an increase in ionic strength could also cause a contraction in the polymer coils, eventually reducing the accessibility of the catalytic sites to reactants. Although the influence of diffusion was apparently not significant as far as the overall 


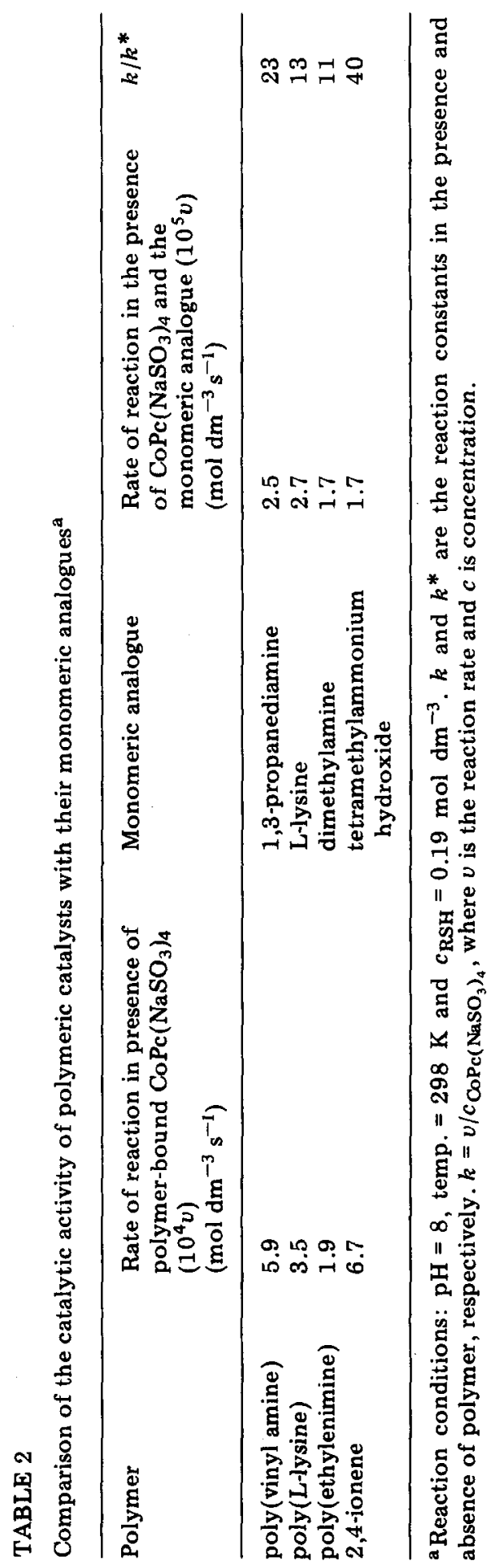


activation energies [4] for the $\mathrm{CoPc}\left(\mathrm{NaSO}_{3}\right)_{4} / \mathrm{PVAm}$ catalyst were concerned, such contraction effects cannot be entirely excluded.

\section{Effect of polymer charge}

In a recent study [7], a linear increase in the reaction rate with increasing polymer charge density was observed when copolymers of vinyl amine and vinyl alcohol were used as polymeric ligands for $\mathrm{CoPc}\left(\mathrm{NaSO}_{3}\right)_{4}$. To check whether this behaviour is a general characteristic for other polycationic thiol oxidation catalysts, the influence of charge density in the 2,4-, 2,6- and 2,10-ionenes on the reaction rate has been investigated. In order to enable comparison with results previously obtained for the vinyl amine-vinyl alcohol copolymers [7], the dimensionless linear charge density parameter $(\lambda)$ was calculated for the polycations, using the rigid rod cell model for polyelectrolytes proposed by Katchalsky [12]. Such $\lambda$ values have been calculated from eqn. (2)

$\lambda=\sigma e^{2} / 4 \pi \epsilon b k T$

where $e=$ proton charge; $\sigma=$ degree of ionisation of the polymer $(\sigma=1$ for ionenes, $\sigma=0.35$ for PVAm at $\mathrm{pH}=7.8$, see Fig. 2); $\epsilon=$ dielectric constant; $b=$ average linear distance between ionisable (ionised) groups; and $k T=$ Boltzmann term. In this equation all the quantities should be expressed in SI units; if cgs units are employed the $4 \pi$ factor should be omitted. Some typical $\lambda$ values are listed in Table 1 .

The results shown in Fig. 4 indicate that an almost linear relationship is also observed between the reaction rate and the polymer charge density for the ionenes studied. However, the shift between the data obtained for the ionenes and those for the amine-alcohol copolymers indicates that at a constant $\mathrm{pH}$ the reaction rates are not solely determined by the charge density. This shift may be explained by the difference in polarity between the chain segments in the two types of polymer. Thus, the copolymers

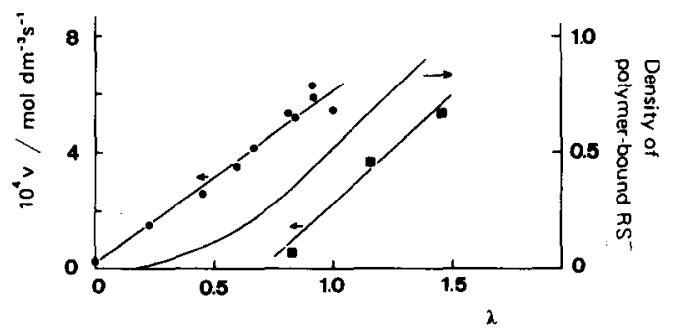

Fig. 4. A plot of the rate of reaction as a function of the linear charge density $\lambda$ on the polycationic ligands $\left(c_{\mathrm{RSH}}=0.3 \mathrm{M}\right)$. The data are depicted as follows: $\bullet$, copolymers of vinyl amine and vinyl alcohol $(\mathrm{pH}=7.8)$, data obtained from ref. 7 ; , ionenes $(\mathrm{pH}=$ 7.4). The calculated polymer-bound counterion density ( $\mathbf{R S}^{-}$) is shown as a function of $\lambda$ on the right vertical axis. This was calculated as $\operatorname{RS}_{\mathrm{bound}}^{-}=\left(1-\phi_{\mathrm{p}}\right) \lambda$, where $\phi_{\mathrm{p}}$ is the osmotic coefficient. The $\left(1-\phi_{p}\right)$ term reflects the mole fraction of counterions 'bound' to the polymer either by condensation or by the effect of Debye-Hückel interactions on the uncondensed counterions [12]. 
TABLE 3

Activation parameters for the oxidation of thiols in the presence of polycations at $298 \mathrm{~K}$ and $\mathrm{pH} 7.8$

\begin{tabular}{|c|c|c|c|c|c|}
\hline Polymer & $\lambda$ & $k / k^{*}$ & $\begin{array}{l}\Delta G^{\not} \\
\left(\mathrm{kJ} \mathrm{mol}^{-1}\right)\end{array}$ & $\begin{array}{l}\Delta H^{\mp} \\
\left(\mathrm{kJ} \mathrm{mol}^{-1}\right)\end{array}$ & $\begin{array}{l}\Delta S^{\neq} \\
\left(\mathrm{J} \mathrm{mol}^{-1} \mathrm{~K}^{-1}\right)\end{array}$ \\
\hline \multicolumn{6}{|c|}{$\begin{array}{l}\text { vinyl amine-vinyl alcohol } \\
\text { copolymer }\end{array}$} \\
\hline$\alpha=0.20$ & 0.51 & $9.5^{\mathrm{c}}$ & 56.9 & $36 \pm 4^{a}$ & $-70 \pm 10^{a}$ \\
\hline$\alpha=0.39$ & 0.67 & 12 & 56.3 & $36^{\mathrm{a}}$ & $-68^{a}$ \\
\hline$\alpha=0.81$ & 0.99 & 22 & 54.8 & $39^{a}$ & $-53^{a}$ \\
\hline \multicolumn{6}{|l|}{ ionenes } \\
\hline 2,10 & 0.82 & $4^{d}$ & 61.1 & $11 \pm 3$ & $-168 \pm 8$ \\
\hline 2,6 & 1.15 & 28 & 56.3 & 25 & -105 \\
\hline $2,4-$ & 1.45 & 40 & 55.4 & 38 & -58 \\
\hline
\end{tabular}

a Data obtained from ref. 7 .

${ }^{b} \alpha=$ mole fraction of ethylenamine units in the copolymer.

${ }^{c_{1,3-p r o p a n e d i a m i n e}}=2 \times 10^{2} \mathrm{~s}^{-1}$; values of $k$ and $k^{*}$ obtained by extrapolation to $c_{\mathrm{RSH}}=\infty$.

$\mathrm{d}_{k}^{*}$ tetramethylammonium $\mathrm{OH}=83 \mathrm{~s}^{-1} ; c_{\mathrm{RSH}}=0.19 \mathrm{~mol} \mathrm{dm}^{-3}$.

possess very hydrophilic chain segments (amine and alcohol residues), whereas the ionenes have hydrophobic alkyl segments. This fact may account for the minimum threshold level of ionene charge density necessary to induce catalysis.

Figure 4 also shows a plot of the calculated density of the 'bound' polymer counterion $\left(\mathrm{RS}^{-}\right)$against the charge density on the polymer $(\lambda)$, employing polyelectrolyte theories for salt-free solutions [12] in the calculation. The plot shows that the increase in rate induced by polycations equipped with basic functionalities can be explained qualitatively in terms of the enhanced local concentration of thiol anions* in the vicinity of the polymer-attached oxidation sites $\left[\mathrm{CoPc}\left(\mathrm{SO}_{3}\right)_{4}{ }^{4-}\right]$ which results in an enhanced collision frequency. However, the desolvation effects of reactants and activated complex (which are generally observed in all kinds of systems in which a number of charges are confined in a small space) may also be important in any explanation of the observations reported $[13,14]^{* *}$.

This proposed desolvation of the activated complex should be reflected in the magnitude of the activation entropy. Table 3 lists the rate constants and activation parameters for some differently charged copolymers and for ionenes. The increase in $\Delta S_{298}^{\neq}$observed for both polymer types when the polymer charge density is increased fits in with both concepts advanced

*In support of this explanation we have recently observed a cationic micellar catalytic effect for the oxidation of dodecanethiol [15].

**It has been demonstrated with various vinyl amine and vinyl alcohol copolymers that $\mathrm{CoPe}\left(\mathrm{SO}_{3}\right)_{4}{ }^{4-}$ is bound to these differently charged copolymers and hence detachment of $\mathrm{CoPc}\left(\mathrm{NaSO}_{3}\right)_{4}$ is not an explanation for the observations shown in Fig. 4. 
above to account for the observed increase in the rate, i.e. an increase in the local substrate concentration and increased desolvation of the activated complex by the high electrostatic potential of the macroions present. However, for the amine-alcohol copolymers the increase in activation entropy is quite modest relative to that for the ionenes, where $\Delta S_{298}^{\neq}$increases substantially at the expense of a low activation enthalpy. These differences in entropy increase may be explained from the viewpoint of dehydration of the activated complex by the increased hydrophobic effects which occur with ionene polymers when the charge density is decreased and the length of the alkyl segments is increased. In this context it might be expected that such differences in the dehydration of the activated complex, as exhibited by changes in the $\Delta S_{298}^{\neq}$values, would be more pronounced for the ionenes than for the copolymers, since the latter are hydrophilic even at very low polymer charge densities. Hence, the influence of hydrophobic ionenes on the activation entropy should diminish as the length of the alkyl chain segments diminishes and with increasing charge density as in the 2,4-ionene. The similar activation entropy values found for the 2,4-ionene $\left(\Delta S_{298}^{\neq}=-58\right.$ $\left.J \mathrm{~mol}^{-1} \mathrm{~K}^{-1}\right)$ and for the vinyl amine-vinyl alcohol copolymer $(\alpha=0.81)$ $\left(\Delta S_{298}^{\neq}=-53 \mathrm{~J} \mathrm{~mol}^{-1} \mathrm{~K}^{-1}\right)$ support this suggestion.

\section{Effect of $p H$}

$\Lambda$ change in the $\mathrm{pH}$ of the reaction medium will seriously affect important parameters establishing the catalytic activity, e.g. the amount of basic groups in the polymer domain and thus the amount of thiol anions, the polymer charge (with the exception of the ionenes) and the ionic strength of the reaction medium. The conformation of the polymer coil will also be affected.

In Fig. 5 is shown the effect of $\mathrm{pH}$ on the catalytic activity of the various polymeric ligands. More or less bell-shaped curves are found, as often observed for enzymes [16] where both basic and acidic sites take part in the reaction. 'The importance of basic sites (and hence of $\mathrm{KS}^{-}$) in the catalysed oxidation of thiols is reflected by the increase in the rate at $\mathrm{pH}>4$ as depicted in Fig. 5. All the polymers studied exhibited an optimum $\mathrm{pH}$ value with the reaction rates being reduced at higher $\mathrm{pH}$ values. This rate-retarding effect is more drastic for the polyamines than for the 2,4-ionene. This can be explained in terms of the loss of charge by the polyamines at higher $\mathrm{pH}$ values (Fig. 2) whereas the ionene retains its charge irrespective of $\mathrm{pH}$. This favours a higher catalytic activity for the ionene (as can be deduced from Fig. 4).

The increase in ionic strength at higher $\mathrm{pH}$ as a result of the dissociation of $\mathrm{RSH}$, will cause a retardation in the rate for all the polycations, as is shown in Fig. 3. The optimum pH values observed in Fig. 5 for the polyamines lie in the sequence PEI $<$ PVAm $<$ PLL. This can be explained in terms of the basicity of the amine groups, which also increases in the order PEI $<$ PVAm $<$ PLL as shown in Fig. 2. This means that at a $\mathrm{pH}$ value of 6 , which is the optimum value for PEI, the environment of PLL will be too 

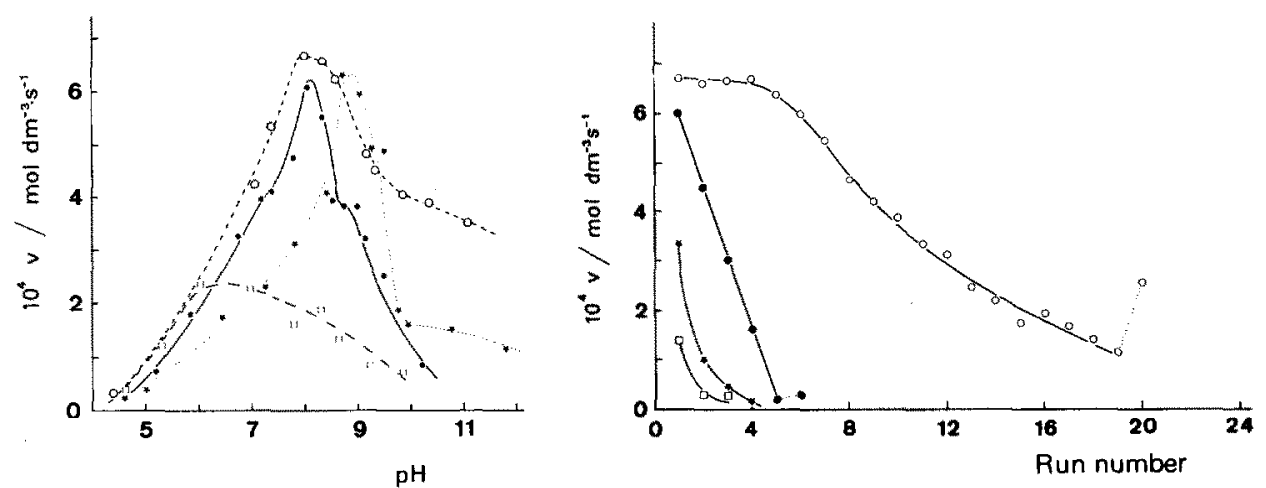

Fig. 5. Influence of $\mathrm{pH}$ on the catalytic activities of the various polycationic catalysts studied. Reaction conditions: $c_{\mathrm{CoPc}\left(\mathrm{NaSO}_{3}\right)_{4}}=1.9 \times 10^{-7} \mathrm{M} ; c_{\mathrm{RSH}}=0.19 \mathrm{M}$. The various curves are identified as follows: $0,2,4$-lonene hydroxide $\left(c_{-\mathrm{N}}=10^{-3} \mathrm{M}\right) ;$, poly $(\mathrm{L}$. lysine) $\left(c_{-\mathrm{N}}=10^{-4} \mathrm{M}\right) ; \bullet$, poly(vinyl amine) $\left(c_{-\mathrm{N}}=10^{-3} \mathrm{M}\right)$; and $\mathrm{D}$, poly(ethylenimine) $\left(c_{-\mathrm{N}}=10^{-3} \mathrm{M}\right)$.

Fig. 6. The stability of polymeric thiol oxidation catalysts in re-use experiments. Reac-

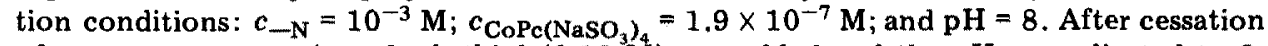
of oxygen consumption, fresh thiol $(0.19 \mathrm{M})$ was added and the $\mathrm{pH}$ was adjusted to 8 . The various curves are identified as follows: $0,2,4$-ionene hydroxide; $\star$, poly(L-lysine); - poly(vinyl amine); and $\square$, poly(ethylenimine). The dotted curve (…...) depicts the addition of a fresh portion of $\mathrm{CoPc}\left(\mathrm{NaSO}_{3}\right)_{4}\left(1.9 \times 10^{-7} \mathrm{M}\right)$.

acidic to allow this polymer to exhibit its optimum activity and hence the $\mathrm{pH}$ optimum is shifted to higher values in this case.

\section{Re-use of catalysts}

Other workers in this institute have shown previously that the stability of the $\mathrm{CoPc}\left(\mathrm{NaSO}_{3}\right)_{4} / \mathrm{PVAm}$ catalyst is poor [17]. Such deactivation was linked to the formation of $\mathrm{H}_{2} \mathrm{O}_{2}$ during the reaction. Apart from the wellknown destruction of $\mathrm{CoPc}\left(\mathrm{NaSO}_{3}\right)_{4}$ by $\mathrm{H}_{2} \mathrm{O}_{2}$, these workers also showed that small amounts of sulfur-containing oxo acids were formed during the reaction, which caused protonation of the amine groups of PVAm and hence a drift in the $\mathrm{pH}$ from its optimum value. In the catalyst re-use tests described here, the latter effect has been eliminated by adjusting the $\mathrm{pH}$ to a value of 8 before each run, and in this way removing the small amounts of acid formed.

The catalyst performance during successive runs is shown in Fig. 6, indicating that the polyamines still exhibit poor stability under these revised conditions, whereas the 2,4-ionene shows a much better performance. The oxygen mass balance data listed in Table 4 show that $\mathrm{H}_{2} \mathrm{O}_{2}$ and sulfurcontaining oxo acids are formed in both the PVAm and ionene systems. This suggests that during oxidation the polymeric amine groups are attacked chemically whereas the quaternary ammonium groups of the ionenes are not. 


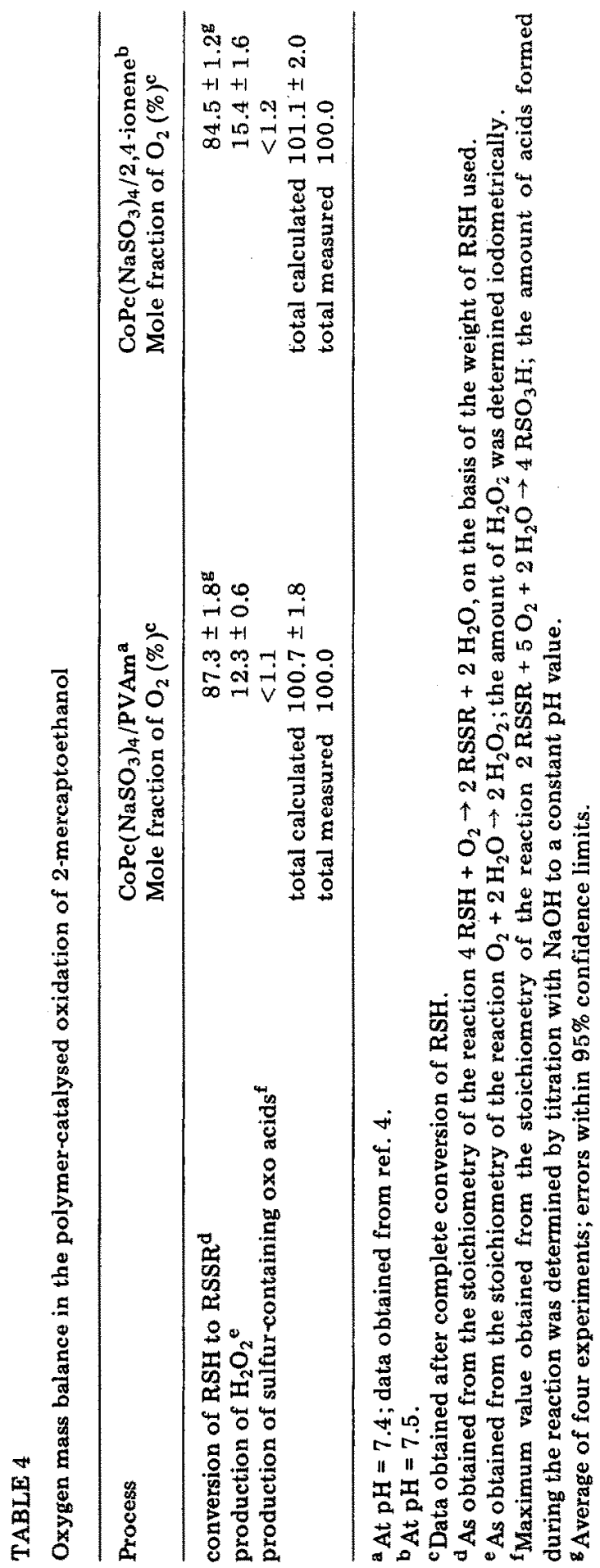


Indeed, there is evidence* that deactivation of polyamine catalysts is principally caused by nucleophilic cleavage of the reaction product RSSR by primary or secondary amines, yielding sulfenamides and thiol $[18,19]$, and thereby destroying the charge and basic functionalities of the polyamines. Since nucleophilic groups are absent from the ionenes, they will be inert to such poisoning; hence in this case the main cause of deactivation will be destruction of $\mathrm{CoPc}\left(\mathrm{NaSO}_{3}\right)_{4}$ by $\mathrm{H}_{2} \mathrm{O}_{2}$. This is confirmed by the observation that the addition of fresh $\mathrm{CoPc}\left(\mathrm{NaSO}_{3}\right)_{4}$ solution to the PVAm catalyst after its use in four runs does not increase its catalytic activity significantly (Fig. 6), whereas a similar addition to the 2,4-ionene catalyst results in a considerable recovery of the catalytic activity even after 19 runs. This latter observation is even more significant when the accumulation of dialcohol (RSSR) in the reaction mixture (up to $25 \% \mathrm{v} / \mathrm{v}$ ) is considered. Such accumulation alone would be expected to lower the rate considerably [20].

\section{Conclusions}

1. Cationic, basic polymers exhibit a large, rate-increasing effect on the $\mathrm{CoPc}\left(\mathrm{NaSO}_{3}\right)_{4}$-catalysed oxidation of 2 -mercaptoethanol relative to their monomeric analogues.

2. Electrostatic effects play a dominant role in the catalysis; the reaction rate varies linearly with the linear charge density on the polycation, and the addition of salt retards the rate of reaction. The presence of hydrophilic side-groups on the polymers promotes the reaction. Increased local concentrations of the thiol anions in the vicinity of the oxidation sites and the dehydration effect of the activated complex account for the observed rate constants and activation parameters.

3. Although axial coordination of $\mathrm{CoPc}\left(\mathrm{NaSO}_{3}\right)_{4}$ by the polymeric ligand may occur (e.g. in PVAm), it is highly unlikely that this accounts for the catalytic effect of the polymers since the addition of 2,4-ionene, which has no coordination tendencies towards $\mathrm{CoPc}\left(\mathrm{NaSO}_{3}\right)_{4}$, also causes a considerable increase in the reaction rate.

4. When $\mathrm{CoPc}\left(\mathrm{NaSO}_{3}\right)_{4}$ is attached to polycations equipped with quaternary ammonium groups, the resulting catalyst exhibits considerably improved catalyst stability in re-use experiments relative to polyamines.

\section{References}

1 N. N. Kundo and N. P. Keier, Russ. J. Phys. Chem., 42 (1968) 707.

2 W. M. Brouwer, P. Piet and A. L. German, Makromol. Chem., 185 (1984) 363.

*Mixtures of PVAm and RSSR yield a thiol odour soon after mixing. They also discolour an iodine solution after acidification, whereas RSSR on its own in aqueous solution does not. 
3 W. M. Brouwer, P. Piet and A. L. German, Polym. Bull., 8 (1982) 245.

4 W. M. Brouwer, P. Piet and A. L. German, J. Mol. Catal., 22 (1984) 297.

5 J. H. Schutten and J. Zwart, J. Mol. Catal., 5 (1979) 109.

6 W. M. Brouwer, P. Piet and A. L. German, Polym. Commun., 24 (1983) 216.

7 W. M. Brouwer, P. Piet and A. L. German, J. Mol. Catal., 29 (1985) 335.

8 A. Rembaum, W. Baumgartner and E. Eisenberg, J. Polym. Sci., Polym. Lett. Ed., 6 (1968) 159.

9 E. Bortel, A. Kochanowski, W. Gozdechi and H. Koztowska, Makromol. Chem., 182 (1981) 3099 .

$10 \mathrm{H}$. Noguchi and A. Rembaum, Macromolecules, 5 (1972) 261.

11 C. J. Bloys van Treslong and A. J. Staverman, Recl. Trav. Chim. Pays-Bas, 93 (1974) 171.

12 A. Katchalsky, Pure Appl. Chem., 26 (1971) 327.

13 N. Ise, in A. Rembaum and E. Sélégny (eds.), Polyelectrolytes and their Applications, Reidel, Dordrecht, 1975, p. 71.

14 N. Ise, T. Okubo and S. Kunugi, Acc. Chem. Res., 15 (1982) 171.

15 W. M. Brouwer, P. Piet and A. L. German, J. Mol. Catal., 29 (1985) 347.

16 Ch. Tanford, Physical Chemistry of Macromolecules, Wiley, New York, 1961.

17 J. H. Schutten and T. P. M. Beelen, J. Mol. Catal., 10 (1981) 85.

18 H. Al-Rawi, K. A. Stacey, R. H. Weatherhead and A. Williams, J. Chem. Soc., Perkin Trans. 2, (1978) 663 .

19 R. H. Weatherhead, K. A. Stacey and A. Williams, J. Chem. Soc., Perkin Trans. 2, (1978) 800 .

20 J. H. Schutten, Ph.D. thesis, University of Technology, Eindhoven, The Netherlands, 1981. 